\title{
Korelasi antara Stroke dengan Covid-19
}

\author{
Dewi Yulianti Bisri*), Tatang Bisri ${ }^{* *}$ \\ ${ }^{*}$ Departemen Anestesiologi dan Terapi Intensif Fakultas Kedokteran Universitas Padjadjaran-Bandung, \\ ${ }^{* *}$ Departemen Anestesiologi dan Terapi Intensif Fakultas Kedokteran Universitas Jenderal Achmad Yani-Cimahi \\ Bandung
}

\begin{abstract}
Abstrak
Spektrum klinis covid-19 sangat luas, mulai dari gejala minor yang tidak spesifik, seperti demam, batuk kering dan diare, kadang-kadang dikombinasikan dengan pneumonia ringan dan dispnea ringan, hingga pneumonia berat dengan dispnea, takipnea, dan gangguan pertukaran oksigen, menyebabkan disfungsi paru berat, memerlukan ventilasi mekanik, terjadi syok atau kegagalan organ multipel. Bukti awal yang tidak dipublikasikan menunjukkan bahwa pada pasien dengan covid-19 positip terjadi peningkatan risiko stroke iskemik akut. Keluhan neurologik yang sering terjadi adalah sakit kepala, pusing, perubahan pengecapan dan penciuman, lima persen memiliki risiko terjadinya stroke iskemik akut. Coronavirus mempunyai kecenderungan untuk menginvasi susunan sarap pusat (SSP). Perubahan penciuman yang telah dilihat pada covid-19, diposulatkan karena refleks akses dari virus ke otak melalui rute transcribial, walaupun masih perlu dibuktikan untuk severe acute respiratory syndrome coronavirus 2 (SARS-CoV-2). Satu laporan dari Cina menunjukkan bahwa keluhan neurologis seperti dizziness, sakit kepala, hypogeusia dan hyposmia, sering terjadi (sekitar 36\%) pada pasien covid-19. Ensefalopati dan perubahan status mental juga terjadi pada pasien yang telah terinfeksi dengan virus SARS-CoV-2. Penyakit serebrovaskuler lebih sering pada covid-19 yang berat; stroke iskemik akut telah dilaporkan terjadi pada 5,7\% pasien dan gangguan kesadaran pada 15\% pasien, dan 1\% kejadian perdarahan serebral. Kelainan SSP yang memerlukan tindakan pembedahan memerlukan penanganan khusus karena efek teknik dan obat anestesi terhadap SSP, serta perlindungan tenaga kesehatan untuk mencegah transmisi penyakit. Tigapuluh delapan persen pasien covid-19 dengan komplikasi serebrovaskuler meninggal.
\end{abstract}

Kata kunci: coronavirus, covid-19, gangguan neurologis, stroke ischemik, stroke hemorrhagik

JNI 2021; 10 (2): 133-43

\section{Correlation between Stroke and Covid-19}

\begin{abstract}
The clinical spectrum of Covid-19 is very broad, ranging from minor no specific symptom, such as fever, dry cough and diarrhea, some time combined with mild pneumonia and mild dyspnoe to severe pneumonia with dyspnoe, tachypnoe and exchange disorders, leading to severe pulmonary dysfunction, necessary ventilation, shock and multiple organ failure. Preliminary unpublished evidence suggest that patient with covid-19 have an increased risk of acute ischemic stroke. Neurologic complaints that oven occurs are headache, dizziness, change in taste and smell. Five percent risk of developing acute ischemic stroke. Coronavirus has a tendency to invade the central nerve system (CNS). The olfactory change that have been seen in covid-19, are attributed to reflex access from the virus to the brain via the transcribial route, although this remain to be proven for severe acute respiratory syndrome coronavirus 2 (SARSCoV-2). One report from China showed that neurological complaint, such as dizziness, headaches, hypgeusia and hyposmia, were common (about 36\%) in covid-19 patients. Encephalopathy and altered mental status also occurs in patients who have been infected with the SARS-CoV-2 virus. Cerebrovascular disease is more common in severe covid-19; acute ischemic stroke has been reported to occurs in $5.7 \%$ of patients and impaired consciousness in $15 \%$ of patients, and $1 \%$ cerebral hemorrhage was found. CNS disorders that require surgery require special treatment because of the effect of techniques and anesthetics on the CNS, as wll as the protection of health professionals to preventdiseses transmission. Thirty-eight percents of covid-19 patient with cerebrovascular complication died.
\end{abstract}

Key words: coronavirus, covid-19, ischemic stroke, hemorrhagic stroke, neurologic disorders

JNI $2021 ; 10$ (2): 133-43

This article is licensed under a

Creative Commons Attribution-NonCommercial-ShareAlike 4.0 International License.

CDewi Yulianti Bisri, tatang Bisri

(2021) under the CC-BY-NC-SA license 


\section{Pendahuluan}

Laporan pertama infeksi virus ini terjadi pada akhir Desember 2019 di Wuhan, ibu kota provinsi Hubei, Cina. Belakangan, terungkap bahwa virus yang menyebabkan infeksi itu menular di antara manusia. Pada awal Januari 2021, istilah seperti "virus corona baru" dan "virus corona Wuhan" sudah umum digunakan. Pada tanggal 11 Februari 2020, sebutan taksonomi "severe acute respiratory syndrome coronavirus 2" (SARSCoV-2) menjadi alat resmi untuk merujuk pada jenis virus, yang sebelumnya disebut sebagai 2019-nCoV dan virus corona Wuhan. Dalam beberapa jam di hari yang sama, WHO secara resmi mengganti nama penyakit tersebut menjadi Covid-19. ${ }^{1,2}$

Sejak itu, penyakit ini telah menjadi pandemi di seluruh dunia, dengan lebih dari 3,17 juta kematian hingga saat ini. Gejala infeksi SARSCov-2 berkisar dari penyakit asimtomatik hingga sindrom gangguan pernapasan akut (acute respiratory distress syndrome/ARDS) yang mengancam jiwa, pneumonia berat, cedera ginjal akut (AKI), miokarditis, kegagalan multi-organ, dan kematian. Literatur terbaru melaporkan beberapa manifestasi neurologis termasuk serebrovaskular terjadi pada pasien dengan infeksi berat. ${ }^{2}$ Sebagian besar pasien yang terinfeksi SARS-CoV-2 menunjukkan gejala klinis ringan, dimulai dengan demam dan batuk kering, berkembang menjadi penyakit pernapasan ringan atau sedang, dan sembuh tanpa pengobatan khusus. Komplikasi serius dari infeksi, bagaimanapun, tetap menjadi perhatian utama. Sindrom gangguan pernapasan akut, cedera atau gagal jantung akut, cedera ginjal akut, sepsis, koagulasi intravaskular diseminata (disseminated intravascular coagulation/DIC), dan gangguan metabolisme yang mengancam nyawa semuanya telah dilaporkan pada pasien Covid-19, terutama di antara mereka dengan penyakit penyerta atau usia lanjut. Pengetahuan tentang SARS-CoV-2 dan penampilan klinisnya terus berkembang, literatur telah menunjukkan sejumlah besar pasien yang terinfeksi menunjukkan gejala neurologis.3 Baru-baru ini telah didokumentasikan bahwa selain gejala sistemik dan pernapasan, $36,4 \%$
(78/214) pasien dengan Covid-19 mengalami gejala neurologis, termasuk sakit kepala, gangguan kesadaran, dan paresthesia. Pasien yang terkena dampak parah lebih mungkin untuk mengembangkan gejala neurologis daripada pasien yang memiliki penyakit ringan atau sedang. Selain itu, laporan otopsi telah mengungkapkan edema jaringan otak dan degenerasi saraf parsial pada pasien yang meninggal. ${ }^{4}$ Pada 4 Maret 2020, Rumah Sakit Beijing untuk pertama kalinya melaporkan kasus ensefalitis virus yang disebabkan oleh novel coronavirus (CoV) yang menyerang sistem saraf pusat (SSP). Para peneliti mengkonfirmasi keberadaan SARS-CoV-2 dalam cairan serebrospinal dengan sekuensing genom. Ini menggambarkan bahwa Covid-19 berpotensi menyebabkan kerusakan sistem saraf. ${ }^{5}$ Adanya serangan covid-19 pada SSP menyebabkan kita lebih waspada karena kemungkinan kita dihadapkan pada pasien covid-19 yang mengalam stroke perdarahan dan memerlukan tindakan anestesi untuk dilakukan pembedahan, dan dengan pandemi covid-19 yang sekarang sedang berlangsung, sangat penting untuk membuat dokter sadar akan dampak berbagai infeksi $\mathrm{CoV}$ pada SSP.

\section{Patofisiologi}

Lima kasus stroke pembuluh darah besar pada pasien yang berusia di bawah 50 tahun datang ke sistem kesehatan di kota New York. Pada kelima pasien tersebut didiagnosis adanya infeksi parah sindrom pernapasan akut coronavirus 2 (SARSCoV-2). Batuk, sakit kepala, dan menggigil selama 1 minggu terjadi pada wanita berusia 33 tahun yang sebelumnya sehat. Dia kemudian menderita disartria progresif dengan mati rasa dan kelemahan di lengan kiri dan kaki kiri selama 28 jam. Dia menunda mencari perawatan darurat karena takut akan Covid-19. Ketika dia datang ke rumah sakit, skor National Institutes of Health Stroke Scale (NIHSS) adalah 19 (skor berkisar dari 0 hingga 42, dengan angka yang lebih tinggi menunjukkan keparahan stroke yang lebih besar), dan computed tomography (CT) dan CT angiografi menunjukkan infark parsial arteri serebri tengah kanan dengan trombus oklusi sebagian di arteri karotis kanan 
pada percabangan serviks. Kekeruhan ground glass yang tidak merata di apeks paru bilateral terlihat pada CT angiografi, dan pengujian untuk mendeteksi SARS-CoV-2 hasilnya positif. Terapi antiplatelet dimulai; kemudian dialihkan ke terapi antikoagulasi. Pemeriksaan stroke dengan ekokardiografi dan pencitraan resonansi magnetik kepala dan leher tidak mengungkapkan sumber trombus. CT angiografi ulangan pada hari ke 10 rumah sakit menunjukkan resolusi lengkap dari trombus, dan pasien dipulangkan ke fasilitas rehabilitasi. Selama periode 2 minggu dari 23 Maret hingga 7 April 2020, total lima pasien (termasuk pasien yang disebutkan di atas) yang berusia kurang dari 50 tahun. tahun dengan gejala onset baru dari stroke iskemik pembuluh besar. Kelima pasien tersebut dinyatakan positif Covid-19. ${ }^{6}$

Sebuah studi retrospektif data dari wabah covid-19 di Wuhan, Cina, menunjukkan bahwa kejadian stroke di antara pasien yang dirawat di rumah sakit dengan covid-19 adalah sekitar $5 \%$; pasien termuda dalam seri itu berusia 55 tahun. Selain itu, stroke pembuluh darah besar dilaporkan terkait dengan wabah SARSCoV-1 2004 terjadi di Singapura. Koagulopati dan disfungsi endotel vaskular telah diusulkan sebagai komplikasi covid-19. Hubungan tersebut antara stroke pembuluh darah besar dan covid-19 pada pasien muda membutuhkan penyelidikan lebih lanjut. ${ }^{6}$ Meskipun mekanisme pasti SARS-CoV-2 yang menyebabkan patologi serebrovaskular tidak jelas, mungkin ada potensi neuroinvasif yang meningkatkan kejadian stroke, trombosis, dan kondisi neuropsikiatri terkait. Invasi virus ke dalam jaringan dijelaskan melalui enzim pengubah angiotensin dan terbukti di organ subfornical, nukleus paraventrikular, medula ventrolateral rostral, dan nukleus soliter traktus. Sebuah invasi hidung yang mungkin ke bulbus olfaktorius melalui rute trans-sinaptik adalah mekanisme yang diusulkan dari penetrasi sistem saraf pusat.

Invasi virus dari mekanisme dan kemoreseptor di medula dapat menyebabkan gagal napas (Gbr. 1). Coronavirus menginduksi kaskade sitokin inflamasi sistemik, yang dapat menyebabkan koagulopati parah, yang menyebabkan trombositopenia; peningkatan protein C-reaktif, d-di-brinogen. Sistem jalur renin-angiotensin alternatif di otak berkontribusi pada efek antihipertensi, angiogenik, antitrombotik, antiaterosklerotik, pelindung saraf, dan antioksidan. Ini mungkin terganggu karena infeksi coronavirus, mempotensiasi peningkatan kejadian kejadian serebrovaskular (Gbr. 2). ${ }^{7}$

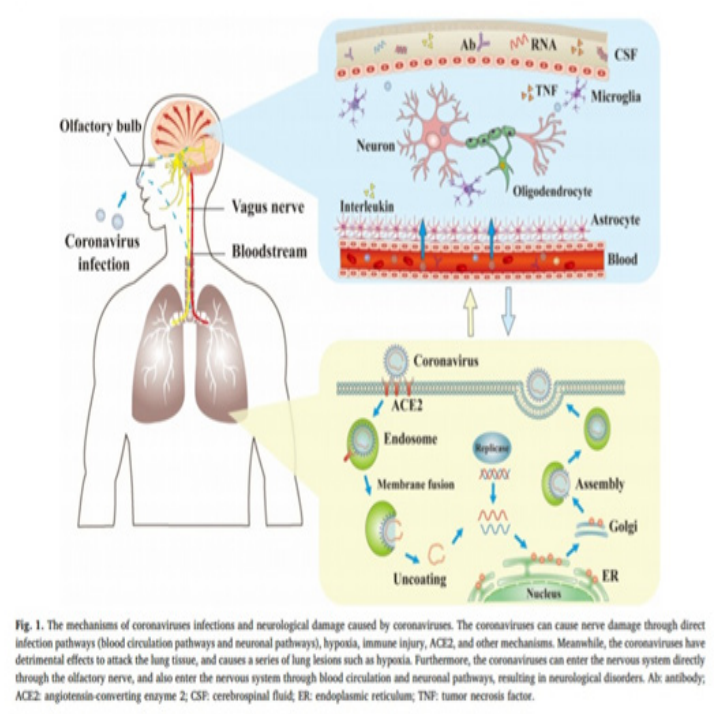

Gambar 1. Mekanisme Infeksi Coronavirus dan Kerusakan Neurologik Dikutip dari Wu Y, dkk. ${ }^{4}$

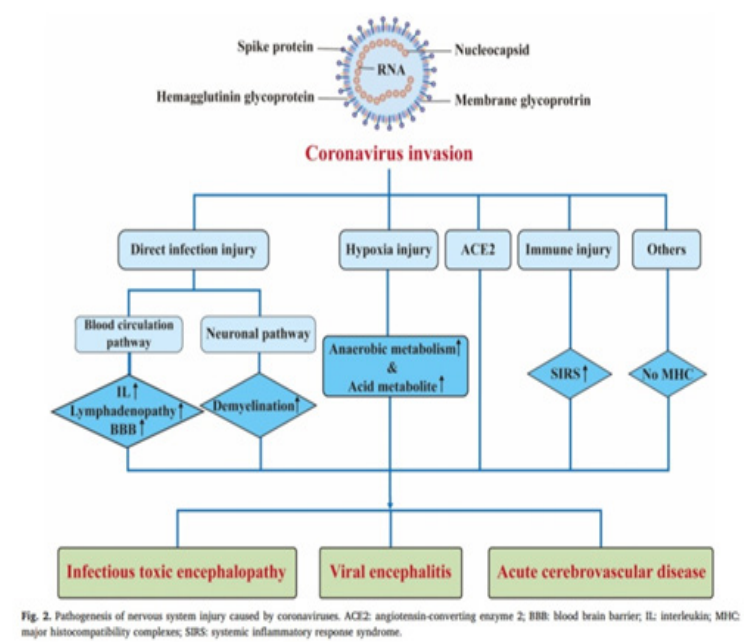

Gambar 2. Patogenesis cedera susunan saraf oleh coronavirus.

Dikutip dari Wu Y, dkk. ${ }^{4}$ 


\section{Karakteristik Klinis secara Umum}

Spektrum klinis penyakit ini sangat luas, mulai dari gejala minor yang tidak spesifik, seperti demam, batuk kering dan diare, kadang-kadang dikombinasikan dengan pneumonia ringan dan dispnea ringan, hingga pneumonia berat dengan dispnea, takipnea, dan pertukaran gas yang terganggu, menyebabkan sekitar $5 \%$ pasien yang terinfeksi terjadi disfungsi paru berat, perlu dilakukan ventilasi, terjadi yok atau kegagalan organ multipel (organ diluar paru). Diantara beberapa parameter klinis dan biokimia yang terkait dengan prognosis yang buruk, peningkatan kadar D-dimer telah mendapatkan perhatian khusus sebagai prediktor perkembangan ARDS, kebutuhan untuk masuk ke unit perawatan intensif (ICU) atau kematian. ${ }^{8}$

Gejala umum penderita adalah demam dan batuk yang sebagian besar berupa batuk kering tanpa dahak yang sangat erat kaitannya dengan virus terutama yang ditularkan melalui saluran pernafasan. Hampir semua kasus yang parah mengalami demam, dan hampir sepertiganya disertai dengan dispnea, nyeri otot, mual, dan beberapa kejadian sakit kepala yang jarang terjadi. Gejala-gejala ini semuanya merupakan manifestasi dari viremia dan mungkin berhubungan erat dengan distribusi reseptor virus ACE. Sejumlah kecil kasus diare mungkin terkait erat dengan virus yang ditemukan pada sampel tinja. Dalam beberapa kasus ringan, gejala di atas diabaikan begitu saja oleh pasien sendiri. ${ }^{9}$

Pemeriksaan CT dada adalah dasar penting untuk skrining, konfirmasi, dan menilai tingkat keparahan pneumonia virus corona baru dan evolusinya. Manifestasi umum dari pemeriksaan CT dada dari semua pasien covid-19 saat masuk adalah ground glass opacity, lesi fokal (bercak, garis atau nodul), dan bercak bilateral, yang juga merupakan manifestasi umum dari sebagian besar pneumonia virus. Ditemukan bahwa kebanyakan kasus memiliki lesi dengan sifat dan luas yang berbeda-beda, dan laporan telah menunjukkan bahwa lesi ini mungkin terkait dengan durasi penyakit. Pada saat masuk rumah sakit, konsolidasi eksudasi patch paru bilateral pada kelompok parah lebih tinggi, dibandingkan dengan kelompok ringan, yang pada kenyataannya konsisten dengan tingkat keparahan penyakit itu sendiri. Sebuah penelitian retrospektif baru-baru ini tentang pneumonia virus menunjukkan prevalensi lesi lobar multipel yang tinggi, yang dapat digunakan sebagai faktor risiko untuk memprediksi tingkat keparahan. ${ }^{9}$

\section{Manifestasi Neurologik dari Covid-19}

Manifestasi neurologik dari covid-19 baru-baru ini telah disampaikan. Bukti awal yang tidak dipublikasikan menunjukkan bahwa pada pasien dengan covid-19 positip terjadi peningkatan risiko stroke iskemik akut. Satu laporan dari Cina menunjukkan bahwa keluhan neurologis seperti dizziness, headache, hypogeusia dan hyposmia, sering terjadi (sekitar 36\%) pada pasien covid-19. ${ }^{1,10-15}$ Ensefalopati dan perubahan status mental juga terjadi pada pasien yang telah terinfeksi dengan virus SARS-CoV-2. Penyakit serebrovaskuler lebih sering pada covid-19 yang berat; stroke iskemik akut telah dilaporkan terjadi pada 5,7\% pasien dan gangguan kesadaran pada $15 \%$ pasien. ${ }^{1,10-15}$

Hasil ini konsisten dengan laporan lain yang dilakukan di Wuhan Cina pada 221 pasien dimana ditemukan kejadian 5\% stroke iskemik akut dan 1\% kejadian perdarahan serebral. Pada penelitian cohort ini, pasien dengan komplikasi serebrovaskular lebih sering pada usia yang lebih tua, mengalami penyakit covid-19 berat, menunjukkan bukti adanya hiperkoagulabilitas dan inflamasi. Akhirnya, 38\% pasien dengan komplikasi serebrovaskuler meninggal. Bersama-sama, laporan-laporan pendahuluan ini menunjukkan bahwa pasien dengan covid-19 lebih sering mendapatkan terapi endovaskular dari stroke iskemik akut dan juga peningkatan risiko stroke perioperatif bila mereka memerlukan pembedahan selama infeksi akut. ${ }^{1,10-15}$ Coronavirus lain yang hampir sama dengan SARS-CoV-2 telah menunjukkan menyerang susunan saraf pusat. Virus SARS-CoV dan Middle East Respiratory Syndrome Coronavirus (MERSCoV) sangat mirip dengan virus SARS- 
CoV-2 dalam struktur dan jalur infeksi dan keduanya menunjukkan menginfeksi susunan saraf pusat (SSP) pada hewan model; batang otak ditemukan terinfeksi berat oleh SARS-CoV dan MERS-CoV. Selanjutnya, infeksi SSP ini berhubungan dengan tingginya laju mortalitas yang kemungkinan karena disfungsi pusat kardiorespirasi di batang otak. ${ }^{1,10-15}$ Perubahan penciuman yang telah dilihat pada covid-19, diposulatkan karena refleks akses dari virus ke otak melalui rute transcribial, walaupun masih perlu dibuktikan untuk SARS-CoV-2. Secara keseluruhan, invasi langsung ke SSP adalah masuk akal, dan merupakan alasan keluhan neurologis yang dilaporkan pada pasien dengan covid-19 positif. ${ }^{1,10-15}$

\section{Tabel 1. Manifestasi Neurological Covid-19}

Keluhan neurologik yang sering terjadi adalah: sakit kepala, pusing, perubahan pengecapan dan penciuman

Lima persen risiko terjadinya stroke iskemik akut.

Coronavirus mempunyai kecenderungan untuk menginvasi SSP.

Dikutip dari: Flexman AM, dkk ${ }^{10}$

Gejala neurologis yang umum penderita covid-19 adalah adanya sakit kepala, pusing, perubahan rasa dan bau. Laporan awal menunjukkan adanya risiko $5 \%$ untuk terjadi stroke iskemik, coronavirus memiliki kecenderungan untuk menyerang sistem saraf pusat. Manifestasi neurologis covid-19 baru-baru ini dijelaskan dan bukti awal yang tidak dipublikasikan menunjukkan bahwa pasien ini berisiko tinggi terkena stroke iskemik. Laporan pra-publikasi baru-baru ini dari Cina menunjukkan bahwa gejala neurologis umum terjadi $(36 \%)$, seperti pusing, sakit kepala, hipogeusia dan hiposmia. Ensefalopati juga telah dilaporkan pada pasien yang terinfeksi virus SARS-CoV-2. Komplikasi neurologis lain juga dapat terjadi akibat covid-19, dan penyakit serebrovaskular termasuk stroke iskemik $(5,7 \%)$ dan gangguan kesadaran (15\%) adalah lebih umum pada penyakit parah. Hasil ini konsisten dengan laporan pra-publikasi lain dari 221 pasien dari Wuhan, Cina, yang menemukan 5\% insiden stroke iskemik akut (5\%) dibandingkan dengan $1 \%$ insiden perdarahan otak. Dalam kelompok ini, pasien dengan komplikasi serebrovaskular lebih cenderung berusia lebih tua, memiliki penyakit yang parah, dan menunjukkan bukti hiperkoagulabilitas dan peradangan. Akhirnya, tiga puluh delapan persen pasien dengan komplikasi serebrovaskular meninggal. Bersama-sama, laporan awal ini menunjukkan bahwa pasien dengan covid-19 dapat datang lebih sering untuk pengobatan endovaskular stroke iskemik akut dan juga berisiko tinggi mengalami stroke perioperatif jika mereka memerlukan pembedahan selama infeksi akut. ${ }^{1,10-15}$

Virus corona lain dengan kemiripan yang dekat dengan SARS-CoV-2 telah terbukti menyerang SSP. Virus SARS-CoV dan MERS-CoV terkait erat dengan virus SARS-CoV-2 dalam struktur dan jalur infeksi, dan kedua virus ini telah terbukti menginfeksi SSP. Pada model hewan, batang otak ditemukan sangat terinfeksi oleh SARS-CoV ${ }^{11}$ dan MERS-CoV. ${ }^{12}$ Lebih lanjut, infeksi SSP terkait erat dengan angka kematian yang tinggi, kemungkinan karena disfungsi pusat kardiorespirasi di batang otak. Kecenderungan untuk neuroinvasion dianggap sebagai fitur umum dari keluarga virus corona, dan virus SARS-CoV-2 harus dianggap memiliki fitur serupa. Pergantian bau yang diamati dengan covid-19 khususnya, telah dipostulasikan ke mencerminkan akses virus ke otak melalui rute transkripsi seperti yang dijelaskan pada patogen lain, meskipun ini tetap menjadi 1 terbukti untuk SARS-CoV-2. Secara keseluruhan, invasi langsung ke SSP masuk akal, dan mungkin menjelaskan beberapa gejala neurologis yang dilaporkan oleh pasien., ${ }^{1,10-15}$

Manifestasi neurologik dari covid-19 baru-baru ini telah disampaikan. Bukti awal yang tidak dipublikasikan menunjukkan bahwa pada pasien dengan covid-19 positip terjadi peningkatan risiko stroke iskemik akut. Satu laporan dari Cina menunjukkan bahwa keluhan neurologis seperti dizziness, headache, hypogeusia dan hyposmia, sering terjadi (sekitar 36\%) pada pasien covid-19. ${ }^{1,10-14}$ Ensefalopati dan perubahan status mental juga terjadi pada pasien yang telah terinfeksi dengan virus SARS-CoV-2. Penyakit serebrovaskuler lebih sering pada covid-19 yang 
berat; stroke iskemik akut telah dilaporkan terjadi pada $5,7 \%$ pasien dan gangguan kesadaran pada $15 \%$ pasien. ${ }^{1,10-15}$ Hasil ini konsisten dengan laporan lain yang dilakukan di Wuhan Cina pada 221 pasien dimana ditemukan kejadian 5\% stroke iskemik akut dan $1 \%$ kejadian perdarahan serebral. Pada penelitian cohort ini, pasien dengan komplikasi serebrovaskular lebih sering pada usia yang lebih tua, mengalami penyakit covid-19 berat, menunjukkan bukti adanya hiperkoagulabilitas dan inflamasi. Akhirnya, $38 \%$ pasien dengan komplikasi serebrovaskuler meninggal. Bersama-sama, laporan-laporan pendahuluan ini menunjukkan bahwa pasien dengan covid-19 lebih sering mendapatkan terapi endovaskular dari stroke iskemik akut dan juga peningkatan risiko stroke perioperatif bila mereka memerlukan pembedahan selama infeksiakut. ${ }^{1,10-15}$ Coronavirus lain yang hampir sama dengan SARS-CoV-2 telah menunjukkan menyerang susunan saraf pusat. Virus SARS-CoV dan Middle East Respiratory Syndrome Coronavirus (MERSCoV) sangat mirip dengan virus SARSCoV-2 dalam struktur dan jalur infeksi dan keduanya menunjukkan menginfeksi susunan saraf pusat (SSP) pada hewan model; batang otak ditemukan terinfeksi berat oleh SARS-CoV dan MERS-CoV. Selanjutnya, infeksi SSP ini

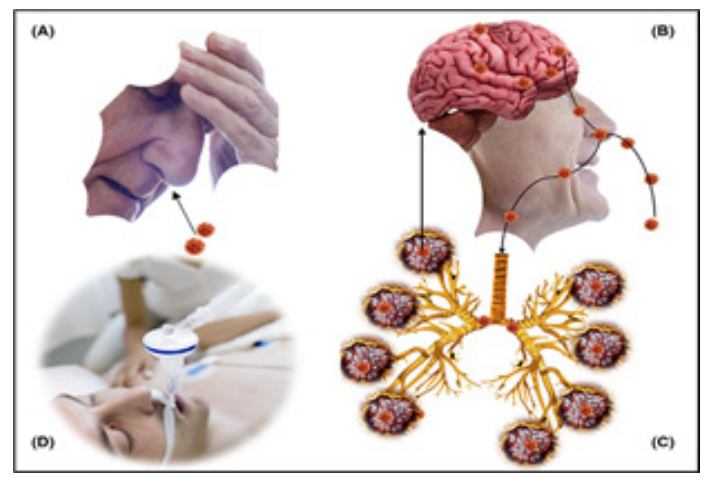

Gambar 3. Manifestasi neurologik covid-19. Demam dan sakit kepala (A) bisa terjadi awal pada pasien covid-19. Manifestasi spesifik yang berhubungan dengan defisit neurologik seperti hilangnya penciuman, pengecapan, ataksia, kejang. Kemungkinan tempat masuknya SARSCoV-2 ke otak melalui cribriform plate (B) atau setelah infeksi paru (C), pada fase awal atau late phases covid-19 mungkin mengakibatkan hilangnya kontrol pernafasan yang memerlukan bantuan ventilasi (D)

Dikutip dari: Baig $\mathrm{MA}^{1}$

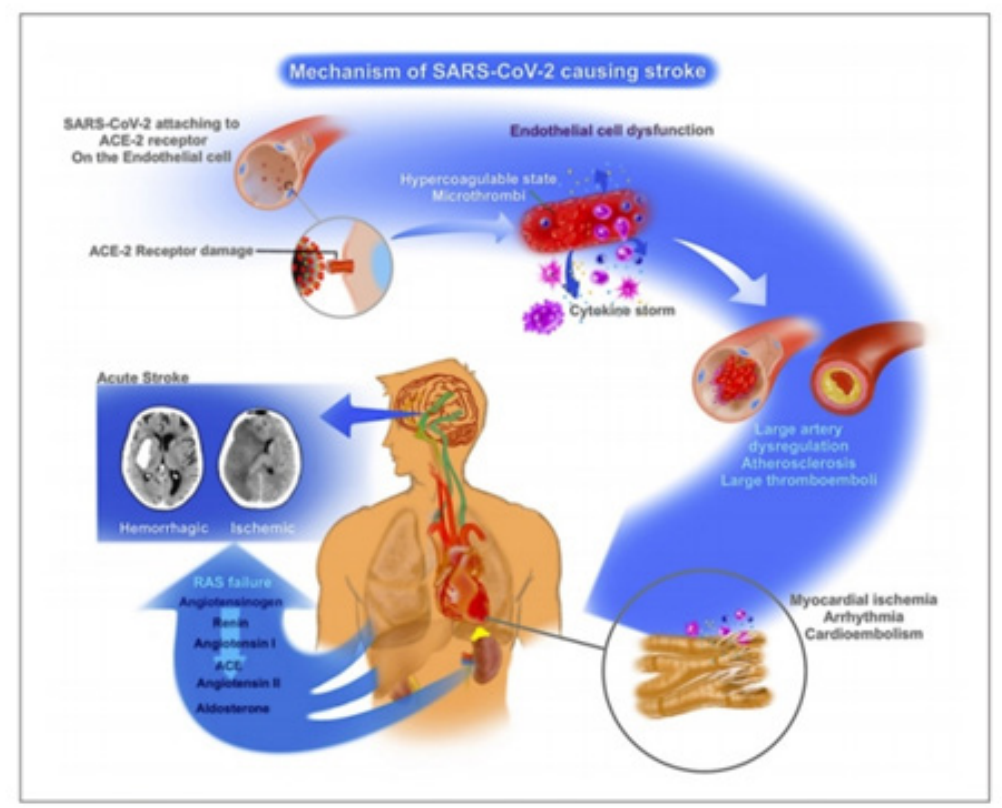

Fig. 2. Mechunium of SARS-CoV-2 causing acule stroke.

Gambar 4. Mekanisme Covid-19 menyebabkan Stroke

Dikutip dari: Kolikonda MK, et al.? 
berhubungan dengan tingginya laju mortalitas yang kemungkinan karena disfungsi pusat kardiorespirasi di batang otak. ${ }^{1,10-15}$

Manifestasi neurologik covid-19: Keluhan neurologik yang sering terjadi adalah sakit kepala, pusing, perubahan pengecapan dan penciuman. Lima persen risiko terjadinya stroke iskemik akut. Coronavirus mempunyai kecenderungan untuk menginvasi SSP. Perubahan penciuman yang telah dilihat pada covid-19, diposulatkan karena refleks akses dari virus ke otak melalui rute transcribial, walaupun masih perlu dibuktikan untuk SARSCoV-2. Secara keseluruhan, invasi langsung ke SSP adalah masuk akal, dan merupakan alasan keluhan neurologis yang dilaporkan pada pasien dengan covid-19 positif. ${ }^{1,10-15}$

\section{Headache}

Delapan penelitian retrospektif melaporkan

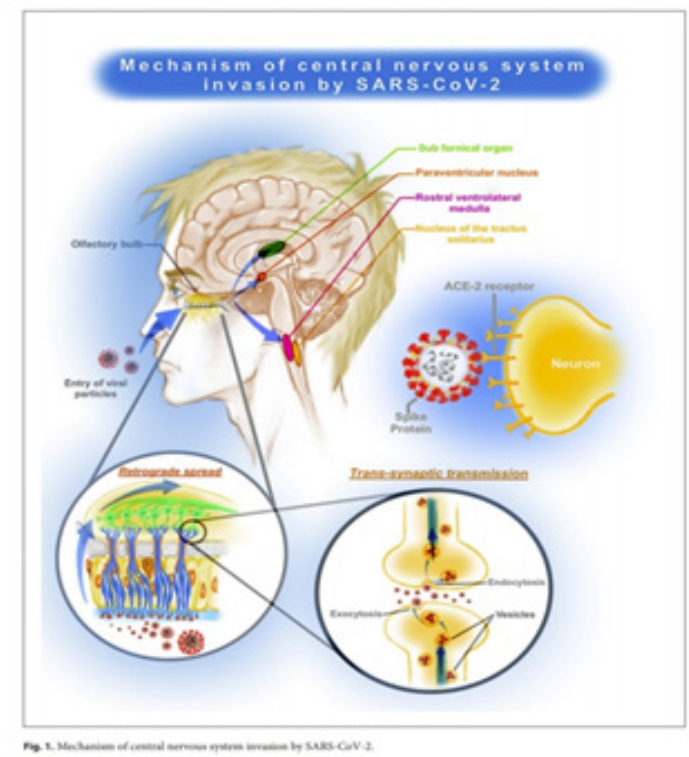

Gambar 5. Mekanisme Invasi SARS-CoV-2 ke SSP

Dikutip dari: Kolikonda MK, et al. ${ }^{7}$

pasien covid-19 mengalami sakit kepala. Kami menemukan bahwa rata-rata keseluruhan dari 19,88\% pasien mengalami sakit kepala (Gbr. 2). Beberapa pasien covid-19 dengan manifestasi neurologis awalnya hanya mengalami demam dan sakit kepala. Namun, beberapa hari kemudian, mereka mengalami batuk, sakit tenggorokan, limfopenia, dan ground class opacity pada gambar CT dada masing-masing. Analisis realtime reverse-transcription PCR (RTPCR) dari usap nasofaring mengkonfirmasi infeksi covid-19 pada pasien ini. ${ }^{3}$

\section{Ischemic stroke}

Sebuah studi observasi retrospektif dari Wuhan, Cina, melaporkan bahwa enam $(2,8 \%)$ pasien, dari 214 kasus covid-19 yang ditinjau, mengembangkan stroke iskemik. Dari enam pasien ini, dua datang ke unit gawat darurat karena timbulnya hemiplegia mendadak tanpa demam atau gejala saluran pernapasan bagian atas. Lima dari enam pasien merupakan kasus covid-19 yang parah. Kadar D-dimer tinggi pada pasien dengan penyakit parah, dibandingkan dengan non-parah, serta pada mereka dengan manifestasi SSP, dibandingkan dengan mereka yang tidak. Sebuah studi observasi retrospektif dari pusat yang berbeda di Wuhan, Cina, menemukan sebelas $(5,0 \%)$ pasien, dari 221 kasus covid-19 yang ditinjau, mengembangkan stroke iskemik akut. Mereka yang memiliki infeksi covid-19 dengan onset baru stroke iskemik lebih cenderung memiliki presentasi SARS-CoV-2 yang parah, usia lanjut $(71,6 \pm 15,7$ tahun versus 52,1 $\pm 15,3$ tahun), dan faktor risiko kardiovaskular yang sudah ada sebelumnya termasuk hipertensi, diabetes, dan penyakit serebrovaskular sebelumnya. Respon inflamasi yang meningkat dan keadaan hiperkoagulasi, ditandai dengan peningkatan kadar CRP dan D-dimer, juga lebih umum di antara pasien ini. Tiga kasus stroke iskemik lainnya dilaporkan di Cina di antara pasien covid-19 yang berusia 4080 tahun. Masing-masing awalnya mengalami batuk kering. Setidaknya 1 minggu kemudian, mereka mengalami kelemahan tungkai, disartria, dan deviasi lidah. CT scan otak mengungkapkan infark ganglia basal dalam satu kasus; temuan normal dilaporkan dalam dua kasus lainnya. Studi laboratorium menunjukkan D-dimer terkait, penurunan kadar fibrinogen, perpanjangan waktu protrombin (PT), dan waktu tromboplastin parsial teraktivasi (APTT). Selain itu, kadar sitokin serum termasuk IL-6, IL-8, dan IL-10, meningkat tajam. Ketiga pasien sembuh dengan hasil fungsional 
yang baik setelah pengobatan stroke dan terapi suportif. ${ }^{3}$ Lapor lima kasus stroke pembuluh darah besar pada pasien yang berusia di bawah 50 tahun dari Amerika Serikat. Hanya tiga kasus yang bergejala untuk covid-19. Rata-rata skor NIHSS adalah 17 saat masuk. CT otak, CT angiografi, dan / atau MRI menunjukkan stroke pembuluh darah besar yang parah pada semua pasien. Semua kecuali satu menjalani trombektomi mekanis. Di antara pasien ini, D-dimer, ferritin, PT, dan APTT meningkat sementara tingkat fibrinogen berkurang. Satu dipulangkan, dua dipindahkan ke fasilitas rehabilitasi, dan dua di ICU/unit stroke pada saat laporan.,

\section{Intracerebral Hemorrhage}

Sebuah studi observasi retrospektif dari Wuhan, Cina, melaporkan satu $(0,45 \%)$ pasien, dari 221 kasus covid-19 yang ditinjau, yang mengalami perdarahan intraserebral. Dia adalah seorang pria perokok berusia 62 tahun yang dibawa ke rumah sakit dengan kasus covid-19 yang parah. Sekitar seminggu kemudian, dia mengalami perdarahan intrakranial dan meninggal. Dari catatan, tekanan darahnya rata-rata $150 / 80 \mathrm{mmHg}$ selama pengobatan. Ada dua laporan kasus dari Iran, satu dari laki-laki 79 tahun tanpa riwayat medis hipertensi atau terapi antikoagulasi dan satu lagi dari seorang wanita 54 tahun dengan riwayat hipertensi. Keduanya muncul dengan kehilangan kesadaran akut yang didahului oleh demam dan batuk kering. Glasgow Coma Scale (GCS) awal untuk mereka masing-masing adalah tujuh dan sepuluh. Studi koagulasi normal untuk keduanya. CT otak menunjukkan perdarahan intraserebral masif di belahan kanan disertai dengan perdarahan intraventrikular dan subarachnoid untuk yang pertama, dan perdarahan ganglia basal subakut bilateral di yang terakhir, dan CT scan paru menunjukkan kekeruhan ground-glass bilateral dalam kedua kasus. Penulis masingmasing menduga perdarahan intrakranial adalah sekunder akibat infeksi SARS-CoV-2 pada kedua kasus. ${ }^{3}$

\section{Hubungan antara infeksi Covid-19 dan kejadian Gangguan Neurologik}

Dalam salah satu laporan pertama tentang temuan neurologis selama wabah covid-19 di
Wuhan, Cina, manifestasi neurologis terdapat pada $78 / 214$ pasien $(36,4 \%)$ dan terbagi dalam 3 kategori: sistem saraf pusat (pusing, sakit kepala, gangguan kesadaran, penyakit serebrovaskular akut, ataksia, dan kejang), sistem saraf perifer (gangguan rasa, gangguan bau, gangguan penglihatan, dan nyeri saraf), dan otot-skeletal. ${ }^{16}$ Stroke, ataksia, kejang, dan tingkat kesadaran yang menurun paling sering terjadi pada pasien yang terkena dampak parah. Dalam studi retrospektif pasien yang dirawat di satu pusat di Wuhan, 11/221 pasien dengan covid-19 mengembangkan stroke iskemik akut, 1 trombosis sinus vena serebral, dan 1 perdarahan otak. Namun, pasien dengan komplikasi parah ini lebih cenderung berusia lanjut dan memiliki komorbiditas medis, terutama faktor risiko vaskular seperti hipertensi. Ensefalopati hipoksia telah didiagnosis pada $20 \%$ dari 113 pasien yang meninggal dengan virus covid-19. Insiden komplikasi trombotik sebesar $31 \%$ pada pasien ICU dengan infeksi covid-19telah didokumentasikan pada 184 pasien ICU dengan pneumonia covid-19 yang terbukti, 23 di antaranya meninggal (13\%). Dalam meta-analisis dari 6 studi pada pasien dengan Covid-19, penyakit serebrovaskular diidentifikasi sebagai faktor risiko bersama dengan hipertensi, diabetes, penyakit paru obstruktif kronik, dan penyakit kardiovaskular. Gambaran neurologis lainnya diamati pada kasus yang parah, termasuk kebingungan, tanda saluran kortikospinalis difus, dan sindrom diseksekutif. Penilaian lengkap tanda-tanda neurologis seringkali sulit karena blokade neuromuskuler yang diinduksi obat atau kematian dini. Polineuropati demielinasi inflamasi akut dan sindrom Miller-Fisher juga diamati. Terjadinya kejadian serebrovaskular pada pasien dengan hipertensi arteri dan penyakit kardiovaskular mungkin terkait dengan efek langsung dari infeksi itu sendiri atau respons host yang tidak tepat. Namun, dalam laporan kasus dan seri kecil, kemungkinan kebetulan tidak dapat dikesampingkan. ${ }^{15}$

\section{Coronavirus Lain dan Gangguan Neurologik} Severe Acute Respiratory Syndrome (SARS) adalah penyakit pernapasan zoonosis yang disebabkan oleh virus Corona (SARSCoV) yang dimulai di Asia Tenggara dan menyebar ke 
negara lain pada tahun 2003. SARS-CoV dapat menyebabkan beberapa penyakit saraf, termasuk polineuropati, ensefalitis, dan stroke iskemik aorta. Studi otopsi menunjukkan bahwa tandatanda edema serebral dan vasodilatasi meningeal dapat dideteksi pada kebanyakan kasus SARS. Selanjutnya, infiltrasi monosit dan limfosit di dinding pembuluh darah, perubahan iskemik neuron, demielinasi serabut saraf, dan partikel SARS-CoV dan urutan genom dapat dideteksi di otak. $^{16}$

Penyakit zoonosis lainnya adalah Middle East Respiratory Syndrome (MERS) yang pada tahun 2012 menandai masuknya MERS-CoV, virus korona yang sangat patogen yang diperkenalkan ke populasi manusia. MERS-CoV juga diketahui berpotensi neuroinvasif, dengan $25,7 \%$ pasien mengalami kegilaan dan 8,6\% mengalami kejang. Gejala neurologis yang terjadi selama proses infeksi juga termasuk gangguan kesadaran, kelumpuhan, stroke iskemik, GBS, dan keracunan atau neuropati menular. Seropositif untuk virus corona telah dilaporkan dalam berbagai gangguan neurologis, termasuk ensefalitis, neuritis optik, multiple sclerosis, dan penyakit Parkinson. ${ }^{16}$

\section{Hubungan Covid-19 dan Stroke}

Fasilitas medis mengalami penundaan yang sangat lama sebelum pasien mencari perhatian untuk keadaan darurat akut. Baru-baru ini, terjadi penurunan $39 \%$ dalam ketepatan waktu orang yang menerima evaluasi stroke akut berdasarkan tinjauan database neuroimaging dari perangkat lunak RAPID platform (iSchemaView). Tingkat stroke yang baru didiagnosis telah menurun sebesar 38\% selama periode COVID ini, sementara proporsi oklusi pembuluh darah besar yang baru menjadi dua kali lipat dalam penelitian retrospektif satu pusat. Hubungan antara covid-19 dan oklusi pembuluh darah besar dilaporkan pada 5 pasien muda. Di antara 221 pasien China yang dirawat di rumah sakit karena covid-19, ${ }^{11}$ terbukti mengalami stroke iskemik akut. Waktu rata-rata dari infeksi SARSCoV-2 hingga deteksi penyakit serebrovaskular adalah sekitar 12 hari. Sebuah penelitian retrospektif rumah sakit mendokumentasikan 4 orang dengan diagnosis terkonfirmasi SARS-CoV-2 dan stroke akut yang terbukti pencitraan. Pengamatan ini meningkatkan kekhawatiran tentang kemungkinan hubungan covid-19 dengan stroke akut. ${ }^{6}$

\section{The SNACC Consensus}

Stroke perioperatif dapat menjadi hasil yang buruk bagi pasien bedah dan keluarganya dan penelitian lebih lanjut jelas diperlukan. Pengakuan pasien berisiko tinggi untuk stroke selama atau setelah noncardiac, operasi nonneurologic sangat penting. Faktor risiko yang konsisten termasuk usia lanjut, penyakit ginjal dan riwayat stroke atau serangan iskemik transien. Kelanjutan beta blocker dan statin penting untuk pencegahan; jika diindikasikan,

Table 1. Manifestasi Neurologik Covid-19 yang Disebabkan oleh SARS-CoV-2.

\begin{tabular}{ll}
\hline Akut & Post viral \\
\hline Anosmia & Acute disseminated encephalomyelitis \\
Mialgia/mioitis & Acute necrotizing hemorrhagic encephalopathy \\
Encepalopati & Transverse myelitis \\
Stroke & Guillain-Barré syndrome \\
Meningitis/encephalitis & Multisystem inflammatory syndrome (Kawasaki's \\
& disease) \\
Seizures & Myalgic encephalomyelitis/chronic fatigue \\
& syndrome \\
Peripheral neuropathy & Dysautonomia \\
Rhabdomyolysis & \\
\hline
\end{tabular}

Dikutip dari: Nath A., dkk. ${ }^{17}$ 
beta blocker hanya boleh dimulai pada periode perioperatif dengan titrasi yang hati-hati. Bukti terbaru menunjukkan bahwa penggunaan aspirin pada pasien yang berisiko stroke setelah operasi nonkardiak tidak diindikasikan dan dapat meningkatkan risiko perdarahan. Hipotensi intraoperatif harus dihindari pada pasien bedah dengan risiko tinggi stroke perioperatif dan bagi mereka yang duduk di kursi pantai. ${ }^{18}$ Kewaspadaan pasca operasi dan skrining stroke yang tepat untuk pasien bedah risiko tinggi adalah bijaksana. Untuk pasien bedah yang menunjukkan gejala atau tanda stroke, konsultasi neurologi/ stroke yang tepat waktu dan neuroimaging yang muncul sangat penting. Bedah nonkardiak mayor, nonneurologis bukan merupakan kontraindikasi absolut terhadap pemberian $\mathrm{rtPa}$ intravaskular; trombolisis mekanis juga merupakan pilihan bagi mereka yang berisiko tinggi mengalami perdarahan terkait operasi. ${ }^{18}$

\section{Simpulan}

Tim stroke harus waspada terhadap fakta bahwa pasien covid-19 dapat datang dengan keluhan serebrovaskular dan tenaga kesehatan harus menyediakan alat pelindung diri yang sesuai pada setiap pasien yang dicurigai. Rencana harus dikembangkan untuk tidak mengabaikan penanganan kecelakaan serebrovaskular akut, meskipun pengendalian infeksi covid-19 menjadi prioritas utama kami. Diperlukan lebih banyak penelitian untuk mengidentifikasi implikasi neurologis penyakit covid-19.

Intervensi stroke yang tepat waktu dan pengujian korona pada pasien yang tepat sangat penting. Sementara tindakan pencegahan virus Corona sedang dilonggarkan, mengakui hubungan covid-19 dengan penyakit serebrovaskular membantu merencanakan layanan perawatan kesehatan dan harus meningkatkan hasil klinis. Edukasi tentang SARS-CoV-2 dan apa yang harus dilakukan tentang infeksi covid-19 bermanfaat. Meskipun hubungan antara covid-19 dan stroke mendapat perhatian baru-baru ini, bukti saat ini tidak menunjukkan hubungan sebab akibat. Meskipun ada laporan yang diterbitkan tentang penurunan presentasi stroke selama pandemi covid-19, mungkin ada lonjakan patologi serebrovaskular akut dengan meningkatnya munculnya hubungan antara covid-19 dan stroke. Menjaga ketersediaan evaluasi dan/ atau intervensi tepat waktu untuk pasien dengan penyakit serebrovaskular akut sangat penting.

\section{Daftar Pustaka}

1. Baig MA. Neurological manifestation in Covid-19 cause by SARS-CoV. CNS Neurosci Ther. 2020;00:1-3.

2. Avula A, Nalleballe K, Narula N, Sapozhnikov S, Dandu V, Toom S, et al. Covid-19 presenting as stroke. Brain Behav Immun. 2020; S0889-1591(20): 30685-1.

3. Nepal G, Rehrig JH, Shrestha GS, Shing YK, Yadav JK, Ojha R, et al. Neurological manifestations of Covid-19: a systematic review.

4. Wu Y, Xu X, Chen Z, Duan J, Hashimoto K, Yang L, et al. Nervous system involvement after infection with Covid-19 and other coronaviruses. Brain Behav Immun 2020;87:18-22.

5. Wu Y, Xu X, Yang L, Liu C, Yang C. Nervous system damage after Covid-19 infection: Presence or absence? Brain, Behavior, and Immunity 2020;87:55

6. Oxley TJ, Mocco J, Majidi S, Kellner CP, Shoirah H, Singh IP, et al. Large-vessel stroke as a presenting feature of covid-19 in the young. N Engl J Med. 2020; 382(20): e60.

7. Kolikonda MK, Jandrasupali KK, Lippman S. Assosiation of coronavirus disease 2019 and stroke: a rising concern. Neuroepidemiology 2020;54:370-74

8. Marietta M, Ageno W, Artoni A, De Candia E, Gresele P, Marchetti M, et al. Covid-19and haemostasis: a position paper from Italian 
Society on Thrombosis and Haemostasis (SISET). Blood Transfus 2020; DOI 10.2450/2020.0083-20

9. Zheng F, Tang W, Li H, Huang XY, Xie YL, Zhou ZG. Clinical characteristics of 161 cases of corona virus disease 2019 (covid-19) in Changsha. European Review for Medical and Pharmacological Sciences 2020; 24: 3404-10

10. Flexman AM, Abcejo A, Avitisian R, de Sloovere V, Highton D, Juul N, Li S, et al. Neuroanesthesia practice during the Covid-19 pandemic: Recommendation from Society for Neuroscience in Anesthesiology \& Critical Care (SNACC). Journal of Neurosurgical Anesthesiology 2020

11. Bisri DY, Bisri T. Pertimbangan anestesi perioperatif untuk pasien bedah saraf dengan covid-19. Jurnal Neuroanestesi Indonesia 2021;9(1):

12. Mao L, Wang M, Chen S, He Q, Chang J, Hong $\mathrm{C}$, et al. Neurological manifestations of hospitalized patients with covid-19 in Wuhan, China: a retrospective case series study. medRxiv 2020

13. Filatov A, Sharma P, Hindi F, Esoinosa PS. Neurological complications of coronavirus disease (covid-19): encephalopathy. Cureus
2020;12: e7352.

14. Li Y, Wang M, Zhou Y, Chang J, Xian $\mathrm{Y}$, Wang $\mathrm{D}$, et al. Acute cerebrovascular disease following COVID-19: a single center, retrospective, observational study (3/3/2020). Available at SSRN: https://ssrn. com/abstract $=35500252020$.

15. Zoia C, Bongetta D, Veiceschi P, Cenzato M, Meco FD, Locatelli D, et al. Neurosurgery during the covid-19 pandemic: update from Lombardy, northern Italy. Acta Neurochir (Wien) 2020 Mar 28.

16. Beghi E, Feigin V, Caso V, Santalucia P, Logroscino G. Covid-19 infection and neurological complications: present findings and future predictions. Neuroepidemiology 2020;54:364-369.

17. Nath A, Smith B. Neurological complications of covid-19: from bridesmaid to bride. Arq Neuropsiquiatr 2020;78(8):459-60

18. Mashour GA, Moore LE, Lele AV, Robicsek SA, Gelb AW. Perioperative care of patient at high risk for stroke during or after noncardiac, non-neurologic surgery: consensus statement from the Society for Neuroscience in Anesthesiology and Critical Care. J Neurosurg Anesthesiol 2014;00:000-000 